\title{
Integration of Science, Education, Business, and Power in the Digital Environment
}

\author{
Larisa Drobyshevskaya \\ Department of world economy and management \\ Kuban State University \\ Krasnodar, Russia \\ ld@seatrade.ru
}

\author{
Svetlana Kovalenko \\ Department of Economics \\ Southern Institute of Management \\ Krasnodar, Russia \\ kovalenko79.s.a@yandex.ru
}

\author{
Ekaterina Popova \\ Department of Economics \\ Southern Institute of Management \\ Krasnodar, Russia \\ ekaterina-kgu@mail.ru
}

\begin{abstract}
The article presents research results of the process of integration of science, education, business and government as the basis for the progressive development of the national economy. A methodological approach is proposed and the effectiveness of integration interactions of the participants of the innovation ecosystem (on the example of Krasnodar region) is evaluated on the basis of the hierarchy analysis method. The model of integration interaction of education, science, business and government on the basis of digital knowledge platform has been developed. A system of measures is presented, which is aimed at expanding and deepening integration effects in the development of the innovation ecosystem on the basis of selforganization, decentralization of decision-making and collaboration.
\end{abstract}

Keywords: science, education, business, government, integration, digital knowledge platform

\section{INTRODUCTION}

The main changes in recent years - globalization, scientific and technological revolutions, exponential growth of investments into knowledge, mobile communication and Internet users - accelerated the development of the new economics, and new knowledge and breakthrough technologies reformatted the matrix of economic development [1]. These trends have made radical changes in most sectors of the economy in which innovation is carried out.

A key participant in the innovation process is the state, which stimulates its development by providing certain guarantees and benefits, financial and material resources to other participants - to business structures, to educational and scientific institutions.
The relevance of the integration interaction of education, science, business and government as the basis for the progressive development of the Russian economy is due to the fact that the increase in innovative potential has not led to a significant increase in innovative activity of enterprises. In the Global innovation index 2019, Russia ranked 46th out of 129, and in comparison with 2018, its position has not changed. Also relevant for Russia is the problem of the scale of domestic innovation business, which in the total GDP of the country is just over $20 \%$ (Fig. 1). At the same time, in terms of the development of innovation and scientific activity, our country is also significantly behind the industrialized countries, in which up to $95 \%$ of GDP growth is accounted for the new knowledge embodied in technologies, equipment and machinery [2].

The data in Fig. 1 show an insignificant share of research and development expenditure in the country's GDP - just over $1 \%$. 
In publications $[5,6,7,8]$ the problems connected with

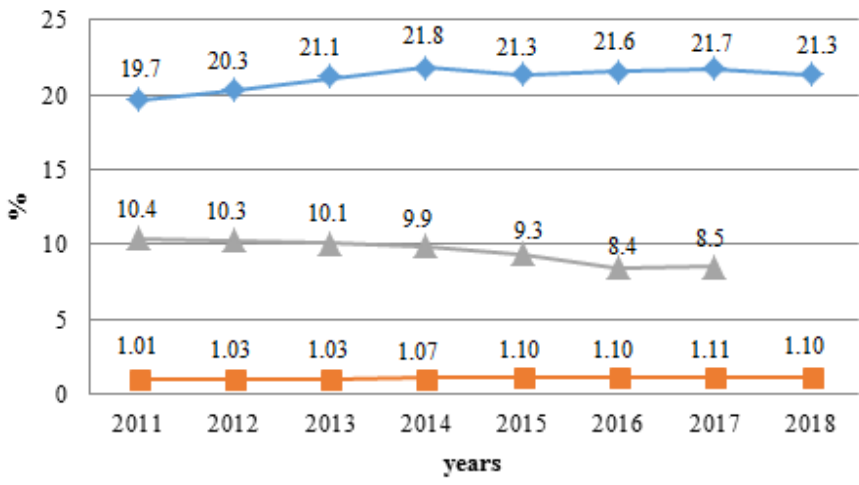

$\longrightarrow$ Share of high-tech and knowledge-intensive industries in Russia's GDP, \%

- Share of domestic ex penditures on research and development in Russia's GDP, \%

- Share of innovation organizations, $\%$

Fig. 1. Main indicators of development of innovation and scientific activity in Russia for $2011-2018, \%$ [3]

At the same time, the volume of internal costs of commercial organizations for research and development is of little importance - during 2000-2018, the share of business as a source of funding for science decreased more than $11 \%$. However, in many developed and rapidly developing countries, this source is considered to be the main one. For example, in the USA business accounts for $64.2 \%$ of research and development costs, in Germany $-65.6 \%$, the Republic of Korea $-74.5 \%$, China $-74.7 \%$, Japan $-78 \%$ [4]. This means that the basis of commercially attractive ideas in developed countries is the development of innovative business, and their practical implementation is achieved through the integration of innovative entrepreneurship, science and education.

Big business is hindered, primarily, by a low level of awareness. Manufacturing companies are often little aware of the innovations that are being created in the country.

In 2017 , less than $10 \%$ of Russian enterprises implemented innovations, while in Germany, $59 \%$ of production companies were actively using new developments, in France - 47\%, in the $\mathrm{UK}-46 \%$. The main reason for such low rates is the lack of conditions for interaction between the innovative and industrial sectors of the economy. Scientific organizations and IT start-ups lack financial and infrastructural resources. And big business, which should be the main consumer of domestic developments, has little involvement in their creation.

In General, the presented data characterizing innovative activity in Russia actualize the need for the development of integration processes, the participants of which are education, science, business community and government.

\section{Literature REVIEW AND RESEARCH METHODS}

This study was based on the fundamental and applied works of foreign and domestic scientists, studying the transformation of interaction forms and models of educational and scientific institutions, business structures and authorities in the knowledge economy. importance to increase innovative interaction role of education, science, business and government powers in considered.

Theoretical and methodological bases for network interaction of education, science and production, evaluation of its effectiveness are developed in the dissertation research [9].

The authors of the articles [10, 11] presented the classification of forms and tools of integration of science, education and business community in the conditions of innovative development of the regional economy. A special role in the work is given to the creation of entrepreneurial universities, aimed at increasing innovation activity. The publication [12] considers the role of research universities, which combine a huge scientific base, innovation centers, research parks and an educational component.

In the publication [13] the concept of the triple helix "University-Enterprise-State" is considered, which appeared as the intersection of two so-called double helices: "UniversitiesEnterprises" and "State-Universities".

The key indicators of integration processes efficiency in the innovative environment, based on the balanced system of indicators of R. Kaplan and D. Norton are offered in the dissertation research [14].

The methodological basis of the study became the methods of analysis, comparison, scientific observation and theoretical generalization. The method of scientific abstraction allowed to reveal a number of key tendencies of formation and development of integration processes in innovative economy of Russia. As a result of the system analysis the characteristic of innovative potential of Russia is presented and the platform of interactions is developed. The comparative analysis was used in the study of integration forms of science, education, business and government in Russia for 2014-2018.

The author's method of assessing the effectiveness of integration interactions of the innovation ecosystem participants (on the example of the Krasnodar region) is based on the use of the hierarchies analysis method of T. Saati [15]. The method is designed for comparative evaluation of the effectiveness of options for building integration relationships at the qualitative level (based on the results of expert evaluations).

The essence of the author's methodology for assessing the effectiveness of integration interactions is a hierarchical decomposition of the key goal (evaluation of the effectiveness of these interactions of the innovation ecosystem participants on the example of Krasnodar region) on the evaluation criteria and further processing of the sequence of judgments of experts on the selected criteria using the matrix of pair comparisons (Fig. 2). restructuring and diversification of economy of Russia are 
in the number of existing and creating parks are Moscow Region (18), City of Moscow (13), the Republic of Tatarstan (4), Sverdlovsk Region (4), Voronezh Region (3), Lipetsk Region (3).

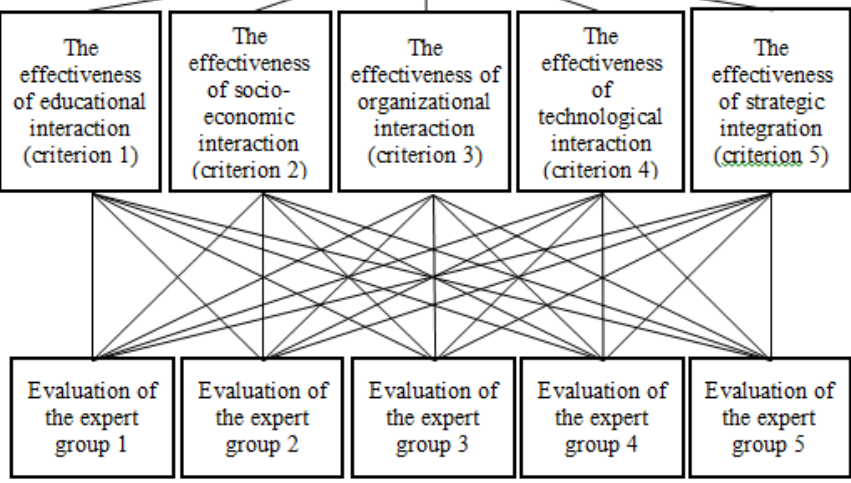

Fig. 2. The scheme for assessing the effectiveness of integration interactions of participants in the innovation ecosystem

To assess the effectiveness of integration (E), the authors set the following score scale: v1 ("excellent") - 90-100 points, v2, ("very good") - 80-89 points, v3, ("good") - 70-79 points, v4, ("satisfactory") - 60-69 points, v5 ("bad") - below 60 points. Thus, in the developed methodology, the integration interaction of science, education, business and government will be considered ineffective if the evaluation results are below 60 points. The final formula for evaluating the effectiveness of integration takes the form:

$$
E=A * V
$$

where E - efficiency of integration interaction; A-matrix of the overall result of the expert assessment; V-matrix of performance evaluation levels.

\section{RESULTS AND DISCUSSION}

Retrospective analysis of the specifics of the integration of education, science, business and government allows us to conclude that Russia has created various forms of integration interaction: science cities, technology parks, clusters, national and research universities, etc.

Technology parks and clusters in Russia are called upon fulfilling the function of a conducting infrastructure that creates the conditions for sustainable growth of the innovative potential of the regions and reduces the costs of innovative companies within the framework of the integration interaction of education, science, business and government (Fig. 3).

According to the Geographic Information System "Industrial Parks. Technoparks. Clusters" of the Ministry of Industry and Trade of Russia, in 2018 there were 157 technology parks functioning in the territory of 53 regions of Russia, including 65 industrial technology parks, of which 49 were operational, 16 were in the process of creation. In 2019, 3344 residents were registered in existing and creating parks. Among all technology parks, $28 \%$ are state projects, $59 \%$ are private and $12 \%$ have a mixed form of ownership. The leaders

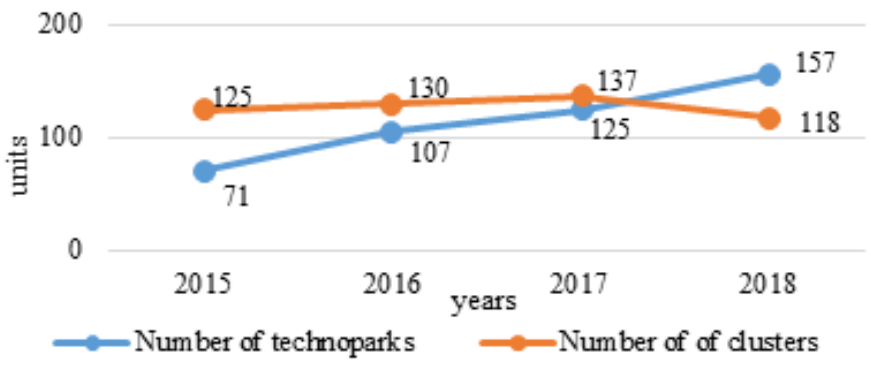

Fig. 3. Dynamics of creating technoparks and clusters in Russia for 2015$2018[16 ; 17]$

Since 2019, state support has been provided for the creation and development of technology parks for small and medium-sized enterprises within the framework of the National project "Small and medium-sized enterprises and the support of individual entrepreneurial initiative", operated by the Ministry of Economic Development of Russia. Six constituent entities of the Russian Federation were approved to have projects for the creation and development of technology parks with a total capital intensity of 2623.6 million rubles in 2018 [18].

Clusters are another priority form of integration of science, education and business in Russia. According to the report "Cluster Policy in Russia: Achieving Global Competitiveness" prepared by the Ministry of Economic Development of Russia, JSC "Russian Venture Company" and NRU "Higher School of Economics", there are more than 110 cluster initiatives in Russia, uniting more than 3 thousand organizations and providing about 1, 3 million jobs. As cluster policy in Russia improves, its focus shifts from test (pilot innovative territorial clusters) and support (cluster development centers) formats to project ones. In particular, the goal for innovation clusters is to achieve global leadership in investment attractiveness [16].

To assess the effectiveness of integration interactions of the innovation ecosystem participants, an expert survey was conducted. Representatives of education, science, business and power structures of Krasnodar region acted as experts. The main results of the analysis are presented in Table I. 
TABLE I. RESULTS OF THE EXPERT EVALUATION OF THE EFFICIENCY OF INTEGRATION INTERACTIONS OF PARTICIPANTS OF INNOVATIVE ECOSYSTEM (FOR EXAMPLE KRASNODAR REGION)

\begin{tabular}{|c|c|c|c|c|c|c|}
\hline \multirow[b]{2}{*}{$\begin{array}{l}\text { Criteria for } \\
\text { assessing the } \\
\text { effectiveness } \\
\text { of integration }\end{array}$} & \multicolumn{5}{|c|}{$\begin{array}{c}\text { Average rating of an expert group of } \\
\text { participants in integration interaction (from } \\
1 \text { to } 5 \text { points) }\end{array}$} & \multirow{2}{*}{$\begin{array}{c}\text { The } \\
\text { overa } \\
\text { ll } \\
\text { avera } \\
\text { ge } \\
\text { score } \\
\text { of } \\
\text { exper } \\
\text { ts. } \\
\text { point } \\
\text { s }\end{array}$} \\
\hline & $\begin{array}{c}1 \\
\text { Educatio } \\
\text { n }(\text { HE. } \\
\text { STR })\end{array}$ & $\begin{array}{c}2 \\
\text { Educati } \\
\text { on } \\
(\text { DPO })\end{array}$ & $\begin{array}{l}3 \\
\text { Scien } \\
\text { ce }\end{array}$ & $\begin{array}{l}4 \\
B u \\
\text { sin } \\
\text { ess }\end{array}$ & $\begin{array}{c}5 \\
\text { Govern } \\
\text { ment }\end{array}$ & \\
\hline $\begin{array}{l}\text { 1. Educational } \\
\text { interaction }\end{array}$ & 3.2 & 3.5 & 3.1 & 2.8 & 3.5 & 3.3 \\
\hline $\begin{array}{l}2 . \quad \text { Socio- } \\
\text { economic } \\
\text { interaction }\end{array}$ & 2.7 & 3.8 & 2.6 & 3.4 & 3.1 & 3.0 \\
\hline $\begin{array}{l}3 . \\
\text { Organizational } \\
\text { interaction }\end{array}$ & 2.1 & 1.9 & 2.1 & 2.4 & 2.8 & 2.3 \\
\hline $\begin{array}{l}4 . \\
\text { Technological } \\
\text { interaction }\end{array}$ & 3.4 & 2.1 & 3.7 & 3.3 & 3.1 & 3.1 \\
\hline $\begin{array}{l}5 . \quad \text { Strategic } \\
\text { interaction }\end{array}$ & 2.1 & 1.8 & 2.0 & 2.8 & 2.9 & 2.3 \\
\hline
\end{tabular}

Data of Table I show that the following criteria were most appreciated by the experts:

- educational interaction-development of the system of practices and internships of students, postgraduates and scientific teaching staff, representatives of science and education in business structures and authorities; participation of representatives of business and government in teaching;

- technological interaction-definition of subject areas of interaction, the volume of joint research and development; implementation of joint work in the field of forecasting scientific and technical development; creation of management system of research and development by representatives of science and education, taking into account the prospective needs of business and government.

In Table II the results of the General assessment of the effectiveness of integration interactions by the innovation ecosystem participants, according to the proposed author's methodology are presented.
TABLE II. RESULTS OF ESTIMATING THE EFFICIENCY OF INTEGRATION INTERACTIONS OF PARTICIPANTS OF INNOVATIVE ECOSYSTEM ACCORDING TO THE ALLOCED CRITERIA

\begin{tabular}{|c|c|c|c|c|c|c|}
\hline \multirow{4}{*}{$\begin{array}{l}\text { Alternative } \\
\qquad \mathrm{s}\end{array}$} & & Criter & a for eval & Iation & & \multirow{4}{*}{$\begin{array}{c}\text { Global } \\
\text { Prioritie } \\
\text { s (Final } \\
\text { Assessme } \\
\text { nt) }\end{array}$} \\
\hline & 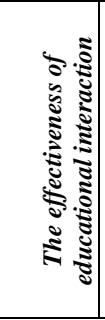 & 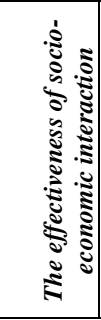 & 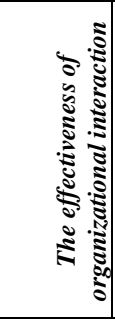 & 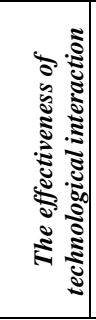 & 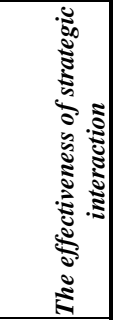 & \\
\hline & \multicolumn{5}{|c|}{ The numerical value of the priority vector } & \\
\hline & 0.4776 & 0.2234 & 0.0378 & 0.2234 & 0.0378 & \\
\hline $\begin{array}{l}\text { Evaluation } \\
\text { of the expert } \\
\text { group } 1\end{array}$ & 0.1207 & 0.0392 & 0.1014 & $\begin{array}{l}0.169 \\
0\end{array}$ & 0.0702 & 0.1106 \\
\hline $\begin{array}{l}\text { Evaluation } \\
\text { of the expert } \\
\text { group } 2\end{array}$ & 0.3444 & 0.5215 & 0.0421 & $\begin{array}{l}0.024 \\
6\end{array}$ & 0.0356 & 0.2894 \\
\hline $\begin{array}{l}\text { Evaluation } \\
\text { of the expert } \\
\text { group } 3\end{array}$ & 0.1090 & 0.0412 & 0.1014 & $\begin{array}{l}0.450 \\
7\end{array}$ & 0.0647 & 0.1682 \\
\hline $\begin{array}{l}\text { Evaluation } \\
\text { of the expert } \\
\text { group } 4\end{array}$ & 0.0445 & 0.2698 & 0.2404 & $\begin{array}{l}0.262 \\
2\end{array}$ & 0.4147 & 0.1649 \\
\hline $\begin{array}{l}\text { Evaluation } \\
\text { of the expert } \\
\text { group } 5\end{array}$ & 0.3814 & 0.1283 & 0.5147 & $\begin{array}{l}0.093 \\
5\end{array}$ & 0.4147 & 0.2668 \\
\hline
\end{tabular}

As a result of the calculations, the overall result of the expert assessment was determined: $\mathrm{A}=[0.110643,0.289412$, $0.168230,0.164873,0.266841]$

Multiplying the resulting matrix by the matrix of levels of efficiency evaluation $\mathrm{V}$, we obtain the overall efficiency:

$$
E=[0.110643,0.289412,0.168230,0.164873,0.266841] *\left[\begin{array}{c}
90 \\
80 \\
70 \\
60 \\
50
\end{array}\right]=68.1 \text {. }
$$

Thus, the result of assessing the effectiveness of integration interactions of participants of the innovation ecosystem of the Krasnodar region amounted to 68.1 points, which corresponds to the level of "satisfactory".

The results obtained, on the example of Krasnodar region, correspond to the General situation in the country. This is evidenced by the results of the expert assessment, conducted at the St. Petersburg international economic forum in the framework of the session "Science, education and business: strategies for integration cooperation". The participants of the session assessed the current level of integration of science, education and business on a five-point scale. The average score was 2.18 points out of 5 . The result almost coincided with the score of the expert group on education. According to experts, the interaction of science and education is at the level of 2.64, the strength of ties between education and business does not exceed 2.45, and science and business-2.27 [19]. 
- revision of the performance evaluation indicators of scientific organizations, especially those that receive a state assignment to conduct fundamental and exploratory research;

- formation of the digital knowledge platform as a modern tool for integration of science, education, business and government.

In the conditions of "information surplus" the authors of the article pay special attention to the formation of the digital platform of knowledge.

The processes of knowledge reproduction, their actualization and active use in all areas of economic activity provide the fastest possible transformation of the results of fundamental research and applied research into innovative products and are a critical factor in the development of competitive solutions [20].

The authors have developed a model of integration interaction of education, science, business and government on the basis of the digital knowledge platform (Fig. 4). management" initiated by the Ministry of science and higher education of the Russian Federation has been launched.

In order to stimulate the development of integration interaction between different participants of innovation activities, new instruments of public-private partnership in the innovation sphere - development institutions, technological platforms, etc. - have also been created and are being developed.

At the same time, the created conditions seem to be insufficient, which is confirmed by the presence of certain barriers to the integration of science, education, business and government:

- the prevalence of bilateral integration in the process of interaction between education, science, business and government;

- low level of Russian business investment in science;

- slow restructuring of the education system in the context of the challenges of the digital revolution;

- low level of stimulation of scientists, carrying out basic research, to do what modern technologies need;

- poor awareness of the business community about innovations that are created in educational and scientific institutions.

In order to eliminate the identified barriers the authors of the article formulated the following recommendations for the activation of all participants of integration interaction in the innovative digital environment:

- development of cooperation between business structures and universities, primarily on the basis of endowment funds;

- integration of digital skills development at all levels of the educational process, including at the preschool level;

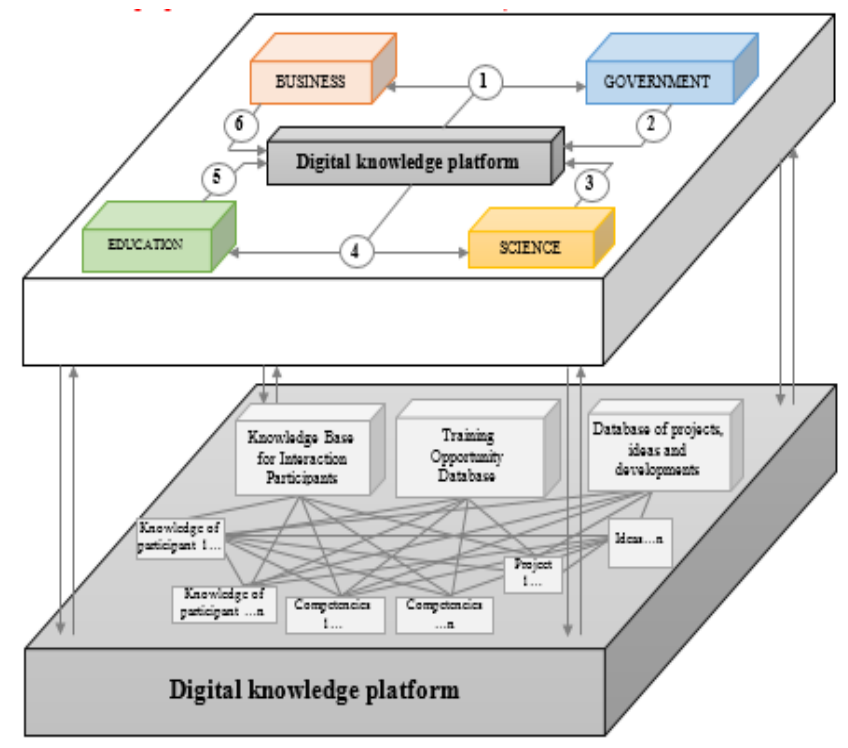

Fig. 4. Author's integration interaction model of education, science, business and government through knowledge management $(1-$ development of intellectual potential, decision support, innovation and development; 2 - legal regulation, financial support, control; 3 - innovative technologies and developments; 4 - orders for services, works; 5 - intellectual resources; 6 innovation and investment projects, financial and other resources)

In the presented model, the digital knowledge platform acts as an integrator of all participants of the collaboration as the highest form of cooperation.

The functioning of these platforms is based on the collection, documentation, assessment, exchange and dissemination of knowledge in relevant industries and sectors of the economy. The main goal of these platforms is to promote cooperation between business, educational and research organizations, create jobs for young professionals, provide the necessary quantity, quality and level of knowledge in certain areas of economic activity with the help of professional employees, accumulate knowledge of all 
In General, world experience shows that the integration of participants of integration interaction in a single information database as well as applying knowledge to simplify decisionmaking, stimulate innovation and commercialization.

In Table III the characteristics of integration interaction participants in the digital environment are presented.

TABLE III. CHARACTERISTICS OF PARTICIPANTS OF INTEGRATION INTERACTION IN INNOVATIVE DIGITAL ENVIRONMENT

\begin{tabular}{|c|c|c|}
\hline Participants & $\begin{array}{l}\text { Objectives of } \\
\text { participants }\end{array}$ & Factors driving integration \\
\hline Science & $\begin{array}{l}\text { The increment of } \\
\text { knowledge, the } \\
\text { discovery of new } \\
\text { properties and } \\
\text { laws of the studied } \\
\text { objects, the } \\
\text { growth of the } \\
\text { economic } \\
\text { potential of } \\
\text { society, the } \\
\text { creation of new } \\
\text { consumer values }\end{array}$ & $\begin{array}{l}\text { Difficulties of commercialization of } \\
\text { scientific developments. } \\
\text { The need to expand the areas of } \\
\text { practical application of innovative } \\
\text { developments. } \\
\text { Increasing the importance of applied } \\
\text { research and development, taking } \\
\text { into account the interests of specific } \\
\text { industries / business structures }\end{array}$ \\
\hline Education & $\begin{array}{l}\text { Training of } \\
\text { specialists with } \\
\text { innovative } \\
\text { thinking, having } \\
\text { the competencies, } \\
\text { necessary for } \\
\text { future professional } \\
\text { activities, and able } \\
\text { to successfully } \\
\text { perform future job } \\
\text { functions in a } \\
\text { competitive } \\
\text { environment }\end{array}$ & $\begin{array}{l}\text { The need to develop practical skills, } \\
\text { innovative and entrepreneurial } \\
\text { abilities of students. } \\
\text { Increasing the attractiveness, } \\
\text { efficiency and funding of training } \\
\text { costs by all participants of the } \\
\text { innovation environment. } \\
\text { The complexity of the demonstration } \\
\text { and use of modern techniques and } \\
\text { technologies used by business } \\
\text { entities, in the course of the } \\
\text { educational process }\end{array}$ \\
\hline Business & $\begin{array}{l}\text { Development of } \\
\text { high-tech } \\
\text { industries, work in } \\
\text { new markets, high } \\
\text { rates of } \\
\text { development }\end{array}$ & $\begin{array}{l}\text { The growing role of organizations } \\
\text { actively using research and } \\
\text { development (agents- innovations } \\
\text { providers). } \\
\text { Most national companies lack the } \\
\text { modern scientific and technological } \\
\text { base that is necessary for innovation. } \\
\text { Lack of specialists able to } \\
\text { implement innovative projects, } \\
\text { develop new areas of knowledge and } \\
\text { acquire new skills and competencies, } \\
\text { as well as, to use them in a specific } \\
\text { production process. } \\
\text { The need to change business models } \\
\text { taking into account the trends of the } \\
\text { digital economy. }\end{array}$ \\
\hline Authorities & $\begin{array}{l}\text { The need to create } \\
\text { a comfortable } \\
\text { environment for } \\
\text { the development } \\
\text { of innovations in } \\
\text { various sectors of } \\
\text { the economy, } \\
\text { science and } \\
\text { education in order } \\
\text { to increase the } \\
\text { innovative } \\
\text { potential of the } \\
\text { country }\end{array}$ & $\begin{array}{l}\text { Insufficient experience of } \\
\text { implementing large innovative } \\
\text { projects in the country. } \\
\text { Lack of budget funds for research } \\
\text { and development. } \\
\text { Low demand for innovative products } \\
\text { and technologies in the country, } \\
\text { which does not contribute to the } \\
\text { activation of innovative business. } \\
\text { The need to consolidate in society } \\
\text { the knowledge and skills, goals and } \\
\text { values associated with the } \\
\text { reproduction of innovative potential, } \\
\text { awareness of the role of science, } \\
\text { education and business }\end{array}$ \\
\hline
\end{tabular}
science, education, business and government is the most effective way to enhance innovation.

\section{CONCLUSION}

Thus, in order to realize the existing potential for the formation of a new economy, Russia needs to create knowledge-a digital basis using the latest approaches to digital technologies, big data management, as well as invest in intellectual human capital to develop future innovations. The key role in this process should be played by the integration interaction of science, education and business, ensuring the interconnection of knowledge production and consumption with the tasks of increasing innovative activity. The role of the state in this process is to create a favorable institutional, legal, organizational and economic environment for all participants of the integration interaction.

The use of the model of integration interaction of education, science, business and government, proposed by the authors through the digital knowledge platform will provide positive results to all participants of integration:

- formation of the technological basis for the creation of new types of economic interactions in the chain " science-education-business-power»;

- convergence of regulatory norms in the innovation sphere at macro-and meso-levels, creation of regulatory competence centers in the regions;

- creation of a new matrix of information exchange between all participants of integration interaction;

- digitalization of business processes, reduction of redundant links, the ability to track the complex chain of use, processing and creation of new "knowledge" objects;

- creation of such a strategic partnership, constant communication, which will contribute to the development of a common mentality of innovative development.

\section{REFERENCES}

[1] L.N. Drobyshevskaya, E.D. Popova, "The development of the knowledge economy of Russia in the era of digital transformations", Creative Economics, vol. 4, 2018, pp. 429-446.

[2] S.G. Boev, "The integration of science, education and production, as the basis for the innovative development of the economy". Economist, vol. 7, 2015, pp. 58-72.

[3] The Federal State Statistics Service of the Russian Federation [Electronic resource] // Rosstat. - URL: http://www.gks.ru.

[4] HSE: RF spending on research and development reached 943.8 billion rubles in 2016 [Electronic resource] // TASS, November 2, 2017. URL: https://tass.ru/ekonomika/4699004.

[5] E.V. Chernyshova, "Training of qualified specialists through the integration of the efforts of education, business and government", Vocational education and labor market, vol. 2, 2014, pp. 12-13.

[6] V.V. Kazakov, "Integration of science and education as the main factor in the development of the national innovation system" Bulletin of 
[14] R.P. Ivanova, Management of integration processes in the innovative environment of industrial types of economic activity, dis.cand. Econ. sciences: 08.00.05, 2018, p. 210.

[15] T.L. Saaty, Decision Making with Dependence and Feedback: The Analytic Network Process, 1996.

[16] V.L. Abashkin, S.V. Artemov, A.N. Gusev et al., Cluster policy: achieving global competitiveness, vol. 2, 2018, p. 346.

[17] The Association of Clusters and Technology Parks of Russia [Electronic resource]. - URL: http://akitrf.ru.

[18] Geoinformation system "Industrial parks. Technoparks. Clusters" [Electronic resource] // Ministry of Industry and Trade of Russia. URL: https://www.gisip.ru/\#!ru/stats/.

[19] T. Matveeva, "A versatile triangle: how to combine science, education and business", Scientific Russia, vol. 6, 2019.

[20] M.N. Sidorov, I.N. Shapkin, "From raw materials to the innovative economy of Russia", Power, vol. 3, 2008, pp. 3-8.

[21] I.R. Lyapina, O.A. Stroeva, "Integration of business, education and science at the regional level", Bulletin of VolSU. Series 3, Economics. Ecology, vol. 19(3), pp. 31-38.

[22] A.G. Sanina, "Conditions for the integration of science, education and business in modern Russia", Sociological Studies, vol. 7, 2010, pp. 122129.

for a Renewed, 2002, p. 26.
[13] H. Etzkowitz, The Triple Helix: University-industry-government innovation in action, 2008, p. 176. 